\title{
Role of the bowhead whale as a predator in West Greenland
}

\author{
Kristin L. Laidre ${ }^{1,3, *}$ Mads Peter Heide-Jørgensen ${ }^{1}$, Torkel Gissel Nielsen ${ }^{2}$ \\ ${ }^{1}$ Greenland Institute of Natural Resources, Box 570, 3900 Nuuk, Greenland \\ ${ }^{2}$ National Environmental Research Institute, Department of Marine Ecology, Frederiksborgvej 399, PO Box 358, \\ 4000 Roskilde, Denmark \\ ${ }^{3}$ Present address: Polar Science Center, Applied Physics Laboratory, University of Washington, 1013 NE 40 th Street, Seattle, \\ Washington 98105, USA
}

\begin{abstract}
We examined the spatial and temporal linkage between primary production, zooplankton distribution and density, and bowhead whale Balaena mysticetus foraging behavior in Disko Bay, West Greenland using concurrent ship-based oceanographic and net sampling together with instrumentation of whales with satellite-linked transmitters and dive recorders. Estimates of bowhead whale abundance were used in a bioenergetic model to calculate the potential consumption of zooplankton during their 4 mo stay in Disko Bay. Between 2001 and 2006, 30 whales were fitted with satellite transmitters that provided information on daily movements, and 14 whales were tracked with archival time-depth or time-depth-fluorescence recorders that provided detailed dive data. Simultaneous data were collected on water column structure, phytoplankton and zooplankton density, taxa and biomass at 25 stations south of Disko Island in 2003, 2005 and 2006. After the retreat of annual winter sea ice, bowhead whales explored a limited area along the south coast of Disko Island and had high interannual site fidelity. Mean dive depths varied between 53 (SD = 35) and 109 (SD = 41) $\mathrm{m}$ but maximum dive depths were $>400 \mathrm{~m}$. Most dives targeted the bottom and dive durations $>40$ min were observed for several whales. Available prey for bowhead whales was dominated by calanoid copepods, with Calanus finmarchicus, C. glacialis and C. hyperboreus occurring at 90 to $100 \%$ of all stations between 0 and $50 \mathrm{~m}$ and contributing $78 \pm 25 \%$ of the total biomass. Bottom sampling for epizooplankton in 2006 resulted in unprecedented densities of $C$. finmarchicus, several orders of magnitude higher than at any other depth. Bioenergetic modeling indicated the population consumes 220 US t of zooplankton per day or $>21000$ t during the 4 mo stay in Disko Bay. Although the total biomass of zooplankton in the upper $50 \mathrm{~m}$ of the water column theoretically could support this predation level, benthic zooplankton densities and behavioral data suggest whales target preascension stage epibenthic copepods in high density patches.
\end{abstract}

KEY WORDS: Bowhead whale $\cdot$ Foraging $\cdot$ Zooplankton $\cdot$ Calanus $\cdot$ Greenland

\section{INTRODUCTION}

A fundamental concept in marine ecology is that the fitness of a predator depends on the spatial and temporal synchrony with the production of its prey (Cushing 1974). This is especially true in seasonal environments where the cycle of temperature and solar radiation only allow for short production periods. The spring bloom in high Arctic marine ecosystems is characterized by relatively short, efficient food chains where the large Calanus copepod population grazes directly on the primary producers. After the spring sea ice recession, many marine predators exploit Calanus spp. for nutritional gain and build up of fat deposits. The largest zooplankton predator in this ecosystem is the bowhead whale Balaena mysticetus. Recent estimates 


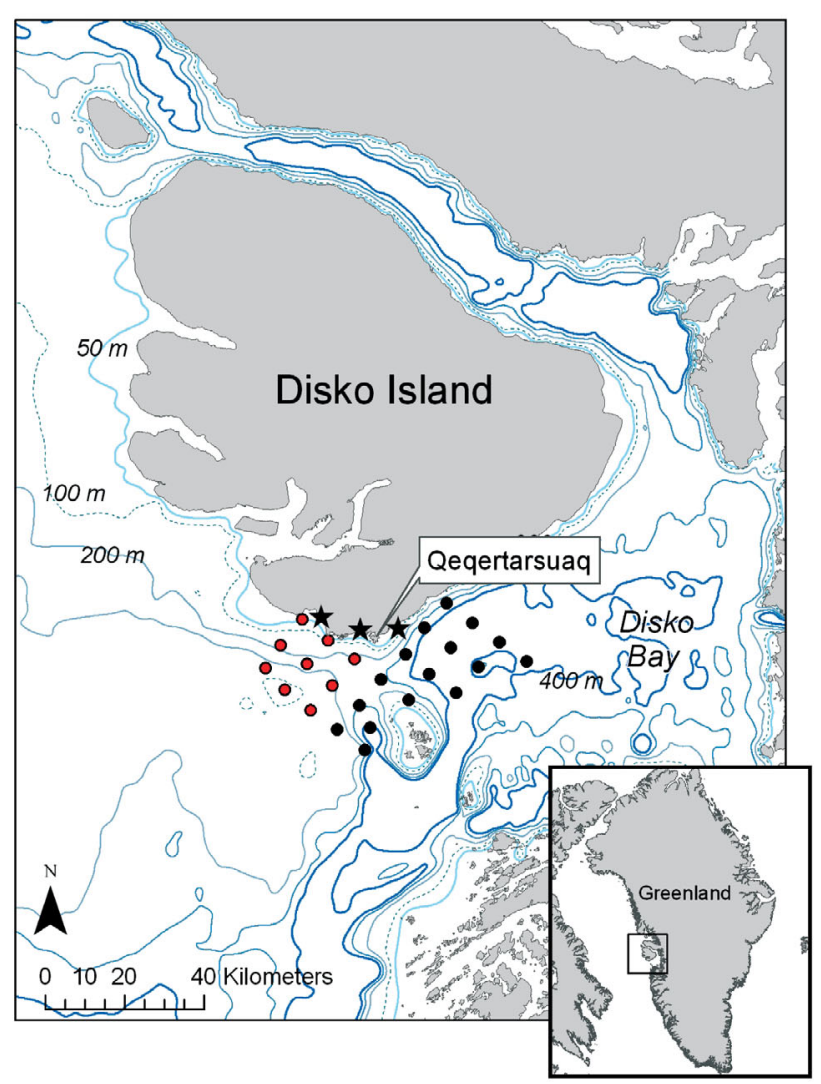

Fig. 1. Disko Bay bathymetry sampling stations for CTD casts and plankton hauls. $(\bullet)$ ): sampled between 5 and 17 May $2003(\mathrm{n}=25)$. ( $)$ : sampled again between 22 April and 1 May $2005(\mathrm{n}=9) .(\star)$ : location of bottom samples in 2006

of bowhead whale abundance off the coast of West Greenland suggest over a thousand whales visit the region between February and May each year (M. P. Heide-Jørgensen unpubl. data). Several hundred whales concentrate in the Disko Bay region (Fig. 1) where they feed intensively before migrating across Baffin Bay in May and June. Satellite tracking studies of bowhead whales have documented specific fidelity to the region south of Disko Island (Heide-Jørgensen et al. 2003, 2006). The highly predictable arrival and departure dates of these whales each spring has been observed dating back to the 1700s (Eschricht \& Reinhardt 1866).

The Disko Bay population of bowhead whales is part of a larger segregated population that ranges into the Canadian high Arctic, Foxe Basin, and Baffin Bay (Heide-Jørgensen et al. 2006). Over $85 \%$ of the whales that visit Disko Bay are females and most are $>14 \mathrm{~m}$ in length (Greenland Institute of Natural Resources unpubl. data). Despite this, few calves and juvenile whales have been observed, which is consistent with observations made during commercial whaling (Eschricht \& Reinhardt 1866).
Disko Bay is located between the sub-Arctic waters of southwest Greenland and the high Arctic waters of Baffin Bay. It is influenced by both the northbound warm West Greenland current of Atlantic Ocean origin and the southbound currents of polar origin in Baffin Bay. The annual sea ice forms early in winter and reaches peak coverage in March. It retreats in April and May and the bay is free of ice by June. During winter, the water column is well mixed and the lack of daylight and ice coverage prevents net growth of the phytoplankton. However, in spring the growth of phytoplankton is exponential and fuels a trophic web that culminates with bowhead whales. Disko Bay is relatively deep (>400 m) and sedimentation of phytoplankton begins shortly after the peak bloom phase (Pedersen et al. 2006); however, frequent extreme wind mixing events reintroduce nutrients from below the pycnocline and refuel the phytoplankton in the surface layer.

Few studies have been conducted on the trophic coupling between whales and their prey, given the dynamic nature of the marine environment and the difficulty in observing or quantifying concurrent whale behavior and prey availability (Croll et al. 2005, Tynan et al. 2005). In the high Arctic, long-term climate change and interannual climate variability are expected to have strong indirect effects on apex predators through trophic decoupling (Laidre et al. 2007). However, a quantitative baseline understanding of the relationship between predators and their environment is required before these effects can be predicted. The primary purpose of this study was to obtain information on bowhead whale movements and diving behavior during the spring foraging period. These data were combined with energetic demands and simultaneous oceanographic and zooplankton sampling to understand how distribution, biomass composition and spatial variability in prey affect the springtime foraging success of the Arctic's largest zooplankton predator.

\section{MATERIALS AND METHODS}

Tracking instrumentation. Thirty Bowhead whales were fitted with satellite tags (Telonics ST-15 and ST16, or Wildlife Computers, SPOT1, SPOT2 and SPOT3 tags) in Disko Bay, West Greenland (Fig. 1). Whales were approached in small boats and tags were pushed under the skin into the blubber layer with an $8 \mathrm{~m}$ long fiberglass pole (for details see HeideJørgensen et al. 2003, 2006) or tags were deployed with an air gun (modified pneumatic line thrower). Tags were deployed in April and May 2001 to 2006 and location data were obtained from polar orbiting 
satellites via the ARGOS data collection system. A biopsy was taken from each animal and length was estimated visually.

Another 14 bowhead whales were also fitted with archival time-depth-recorders (TDRs; MK9, Wildlife Computers) in April or May of 2002, 2003 and 2005 and with WetLabs FLNTUB fluorometers in April or May of 2005 and 2006. Fluorometers and TDRs were mounted on cylindrical shaped floats $(\sim 28 \times 8 \mathrm{~cm})$ with a VHF transmitter (Telonics) and a satellite tag (Wildlife Computers SPOT4) for instrument recovery. Floats were attached to whales using a flat $20 \times$ $25 \mathrm{~mm}$ stainless steel anchoring system modified from traditional Inuit harpoon heads (4 mm thick). All instrument packages were deployed using the pole. While the whale was pursued, the float tags were held in a PVC housing mounted to the pole. Once the harpoon head was imbedded in the blubber of the whale, the float was released from the housing. The float was tethered to a $1.5 \mathrm{~m}$ long stainless steel wire with a corrosive magnesium bolt that released the float from the whale after a predetermined period. Floats were located and recovered by means of the real-time ARGOS satellite and a fine scale VHF search conducted with directional antennas mounted on a 13.6 m boat (RV 'Porsild', Arctic Station, University of Copenhagen) or from a small dinghy. The TDR sampled pressure (depth) and temperature every second and had a total memory of $16 \mathrm{MB}$ and the FLNTUB sampled fluorescence, pressure (depth), turbidity and temperature every second and had a memory of $\sim 65000$ readings.

Location and dive data analysis. Average daily positions were calculated from good quality ARGOS data (LC-0 or better) for each whale. Area use during the residency period in Disko Bay, including all days after instruments were fitted to the whales up to their departure from Disko Bay towards Baffin Island (defined as north of $70^{\circ} \mathrm{N}$ ), was estimated using the 95, 75 and $50 \%$ fixed kernel home range with least squares cross validation using the Animal Movement extension in ArcView (Hoodge \& Eichenlaub 1997). All analyses were conducted with an equal area projection and the area where land overlapped home ranges was subtracted from the home range estimates.

Data from archival dive tags were downloaded for processing and analysis. Drift in the depth values on the TDRs was corrected using the software Instrument Helper v. 0.3 (Wildlife Computers) including both 'Zero-Offset Correction' and 'Dive Analysis' to produce summary statistics for each dive. The minimum depth to be considered a dive was set at $12 \mathrm{~m}$ (approx. the length of a whale) with a surface error of $2 \mathrm{~m}$. Bottom time was defined as $90 \%$ of dive depth. FLNTUB data were converted to measurement units using Wet-
Labs ECOView software and processed using the same parameters as the TDR using Jensen software (MultiTrace Dive Analysis).

Maximum dive depth, dive duration, ascent and descent rates, and proportional time at depth were calculated for each dive for each individual from the raw data collected by the TDR. ANOVA and $t$-tests with a significance level of 0.05 were used to contrast diving between individuals.

Zooplankton and water column sampling. During 5 to 7 May 2003, 25 systematically dispersed stations south of Disko Island in the bowhead whale concentration area (Fig. 1) were sampled for oceanographic properties and zooplankton distribution biomass using a WP-2 plankton net (200 $\mu \mathrm{m}$ mesh and $29 \mathrm{~cm}$ radius) from RV 'Porsild'. Vertical profiles of salinity, temperature, and chl a fluorescence were taken at all stations using a Seabird 25 conductivity, temperature and depth (CTD) meter. At each station, the plankton net was lowered to $50 \mathrm{~m}$ depth and vertically hauled towards the surface at a constant rate of approximately $10 \mathrm{~m} \mathrm{~s}^{-1}$ while the vessel was stopped. After each tow, the net was rinsed on deck and zooplankton were transferred to plastic jars and preserved in $\sim 2 \%$ buffered formalin (final concentration).

Between 22 April and 1 May 2005, 9 stations west of Qeqertarsuaq were selected, comprising a subset of the larger grid to focus on the areas with the highest densities of feeding bowhead whales. The zooplankton was sampled using a submersible pump (900 $1 \mathrm{~min}^{-1}$, HOMA-H500, DIFRES-design) equipped with a flowmeter (Hydrobios), conical net (50 $\mu \mathrm{m}$ mesh size) and a nonfiltering cod end. Samples were collected in 4 depth dependent strata. Subsamples were taken using a sample splitter, and the number of animals and their stages were recorded. The samples were immediately preserved in buffered formalin ( 2\% final concentration). Additionally in 2005, a single standard station located $1.85 \mathrm{~km}$ (1 nautical mile) south of Qeqertarsuaq $\left(69^{\circ} 15^{\prime} \mathrm{N}, 53^{\circ} 33^{\prime} \mathrm{W}\right)$ was monitored weekly between late February and June. Both CTD casts and zooplankton were sampled once a wk through winter and spring, and time series of temperature, salinity, and phytoplankton and zooplankton biomass were obtained.

In 2006, bottom samples of zooplankton were sampled in 3 target coastal areas based on direct observations of bowhead whale feeding. These areas were less than $1 \mathrm{~km}$ from shore (Sorte Sand, Laksebugten and Fortune Bay), generally no more than $140 \mathrm{~m}$ in depth, and located in areas where bowheads predictably made feeding dives. The samples in 2006 were taken using a Hydrobios Multinet (300 $\mu \mathrm{m}$ mesh size) in 5 depth strata with the final strata lying as close to the bottom as possible. Strata were selected by dividing 
the water column into equal segments based on the maximum depth in the area. The net was lowered to the bottom and left for $15 \mathrm{~min}$, and then hauled towards the surface at a constant rate of approximately $10 \mathrm{~m} \mathrm{~s}^{-1}$. In addition, a single sample was taken with a WP-2 plankton net covering the whole water column. The samples were fixed and quantified as described previously.

In all years, mesozooplankton were sorted and identified to the lowest taxonomic level or developmental stage possible. Samples were split to obtain sample sizes of approximately 500 individuals. Each species or category was enumerated for each tow and prosome lengths were measured on up to 10 specimens for each given species or category. Total abundance was estimated by counting the number of individuals in each taxa within a single aliquot and scaling up to the total number of aliquots in each tow. Abundance and length information was used to calculate biomass in each category at each station $\left(\mathrm{mg} \mathrm{C} \mathrm{m}^{-3}\right)$ based on values obtained from the literature (Thor et al. 2005). In 2005 these calculations were conducted at $50 \mathrm{~m}$ increments in the water column down to maximum depths of $200 \mathrm{~m}$. Biomass values were obtained from Hirche \& Mumm (1992) for Calanus species (stages CI-CV) and Metridia longa, from Berggreen et al. (1988) for Acartia spp., from Klein Bretler et al. (1982) for Pseudocalanus species, and from Sabatini \& Kiørboe (1995) for Microcalanus, Oithona and Oncaea species. Carbon content of eggs was obtained from Kiørboe et al. (1985) and nauplii stages from Hygum et al. (2000). For noncopepod species, carbon biomass was estimated for Appendicularia (Uye 1982), Cirripedia (Turner et al. 2001), Euphausidacea (Pedersen et al. 2005), Gastropoda (Hansen \& Ockelmann 1991), Polychaeta (Hansen 1999), Amphipoda (Hirche \& Mumm 1992), Decapoda mysis (Uye 1982), and Chaetognata (Uye 1982). Rare taxa were excluded from biomass calculations, but were enumerated in general categories for 2003 (Table 2).

Spatial gradients in mean copepod (Calanus, Metridia, Pseudocalanus and Oithona spp.) biomass were explored with an inverse distance weighted spatial interpolation model with a search radius $\geq 10$ neighbors (ESRI ArcINFO 9 Geostatistical Analyst) in 2003 and 2005. In 2003 krigging was conducted using all grid stations $(\mathrm{n}=25) 0$ to $50 \mathrm{~m}$ deep. Total potential zooplankton biomass was examined with respect to bathymetry and focal area use of tagged whales. Krigging in the 2005 focal region was based on the 9 grid stations and 1 standard station 0 to $50 \mathrm{~m}$ deep (Fig. 1). The number of stations $>50 \mathrm{~m}$ deep in 2005 was too low for spatial interpolation.

Bioenergetic modeling. A stage and mass structured population model was developed for bowhead whales in Disko Bay using proportional stage classes following directed and opportunistic observations of whales over a $5 \mathrm{yr}$ period. Age classes of bowhead whales in Disko Bay in winter and spring were modeled as $0 \%$ juveniles, $20 \%$ immatures and $80 \%$ adults based on 6 yr of field observations. Sex ratios were set at 85:15 (F:M) based on genetic biopsy studies (Greenland Institute of Natural Resources unpubl. data). A median body mass of $60000 \mathrm{~kg}$ was assumed for sexually mature males and females (Reeves \& Leatherwood 1985), and a median body mass for immatures was assumed to be half of that, or $30000 \mathrm{~kg}$.

A generalized bioenergetic model was developed to quantify the gross energetic requirements of the various population segments. The model was used to estimate the population's daily energy requirements $\left(\mathrm{kcal} \mathrm{d}^{-1}\right)$ by extrapolating recent population abundance estimates of 250 whales $(\mathrm{CV}=0.35)$ for a region corresponding to the home range in Disko Bay (HeideJørgensen \& Acquarone 2002). Basal metabolic rate $\left(B M R\right.$ in $\left.\mathrm{kcal} \mathrm{d}^{-1}\right)$ was calculated as:

$$
B M R=70 \times W^{0.75}
$$

where $W=$ the body mass in kg (Kleiber 1975). Additional energy required for activity, growth and reproduction was added into the model as proportions of basal metabolic rate using the simple bioenergetic model framework:

$$
E R=\frac{[B M R(A+G+R)]}{D E \times A E}
$$

where $E R=$ energy requirement in $\mathrm{kcal} \mathrm{d}^{-1}$ for an individual, $A$ is an activity metabolic multiplier, $G$ is a growth multiplier, $R$ is the reproduction cost multiplier for adult females (costs of fetal metabolism, fetal growth and lactation), $D E$ is the digestive efficiency (digestible energy) and $A E$ is the assimilation efficiency (digestibility of dry matter).

Activity metabolism $(A)$ assumes that active metabolism is a constant multiple of basal metabolic rate (Kenney et al. 1997, Winship et al. 2002). Active metabolism consists of foraging behavior, movement or migration, or age or sex-specific behavior, and has been estimated to be 2 to 5 times the BMR in cetaceans (Lockyer 1981, Kenney et al. 1997). A mean of 2.5 was used following Kenney et al. (1997).

Energy requirements for growth of body tissues and blubber, which decrease with increasing age until physical maturity, can be 110 to $300 \%$ of the maintenance energy required for adults (Innes et al. 1987). Therefore, growth in body mass or production was modeled as additional needs (varying with age) and calculated as a proportion of $B M R$. We let $G$ range from 1.0 to 2.0 for the immature stage classes 
and set $G$ to 0 for adult stage classes, assuming physical maturity was reached and there were no further growth requirements.

Energy for reproduction $(R)$ for adult females was estimated for the costs of pregnancy (energy for fetal metabolism and fetal growth) and lactation. Bowhead whales were assumed to have a calf every 3 yr; consequently, within a given year an 'average' reproducing adult female in the model was pregnant, lactating or resting. A composite energy requirement for pregnancy was based on a fetus assumed to have a $B M R$ proportional to that of an adult per kg (Yasui \& Gaskin 1986), or a mean mass of $6000 \mathrm{~kg}$, estimated as half the birth weight based on $3.5 \mathrm{~m}$ long fetus (Reeves \& Leatherwood 1985) proportional to adult mass-length ratio. The cost of fetal growth (14 mo or 420 d gestation period) was calculated using Brody's (1945) equation for the heat increment of gestation, equal to $4400 M^{1.2}$, where $M$ is the mean birth mass (13000 kg). The cost of lactation was assumed to be 3 times the combined cost of fetal growth and basal metabolism (Yasui \& Gaskin 1986). This resulted in an estimated cost of lactation of approx. twice the basal metabolic rate for a non-lactating adult (Winship et al. 2002). The costs of pregnancy and lactation were combined to create a value for $R$ of 0.6 for the adult female portion of the bowhead population.

Digestive efficiency ( $D E$ ) was assumed to be 0.9 following that for other marine mammals and assimilation efficiency $(A E)$ for cetaceans was assumed to be 0.8 (Lockyer 1981). The energetic value of the Calanus dominated zooplankton was assumed to be $5 \mathrm{~kJ} \mathrm{~g}^{-1}\left(1.18 \mathrm{kcal} \mathrm{g}^{-1}\right)$ with a mean size of $1.0 \times 10^{-4} \mathrm{~g}$ per individual copepod.

Parameter uncertainty was addressed with Monte Carlo simulations where parameter values were randomly selected from sampling distributions that best described their uncertainty. Activity and growth multipliers were sampled from a uniform distribution where $A$ varied between 2 and 3 for all stage classes and $G$ varied between 1 and 2 for immatures. Population size was drawn from a lognormal distribution following Heide-Jørgensen \& Aquarone (2002). Approximately 10000 simulations were used to calculate a mean caloric requirement and confidence intervals for the spring feeding period. These prey demands were used
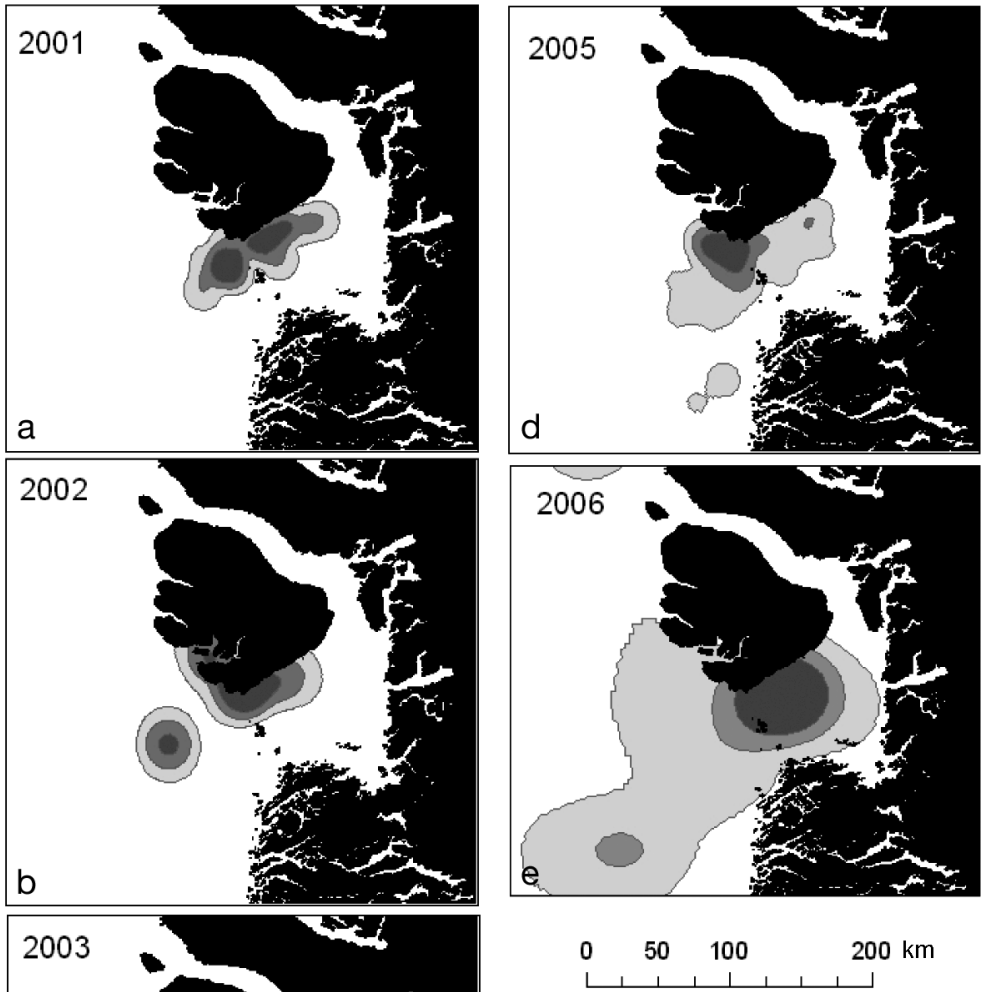

. 2. Balaena mysticetus. Kernel area use in and around Disko Bay between 2001 and 2006. Data were calculated from (a) 5 whales tagged in 2001, (b) 6 in 2002, (c) 3 in 2003, (d) 11 in 2005 and (e) 5 in 2006 using average daily positions while whales remained in Disko Bay before departing on the migration to Canada past $70^{\circ} \mathrm{W}$

to estimate the total amount of zooplankton consumed by the population.

\section{RESULTS}

\section{Area use of satellite tagged whales}

The 30 bowhead whales fitted with satellite tags were all $12 \mathrm{~m}$ or greater in length. Average daily positions were obtained for individual whales tagged in April and May from 2001 to 2006 (Fig. 2). In all years, area use was focused on the southern coast of Disko 
Table 1. Balaena mysticetus. Summary dive statistics collected from TDRs and FLNTUBs deployed on 14 bowhead whales from May 2002 to 2006 in Disko Bay, West Greenland. TDR: Wildlife Computers Time Depth Recorder, FLNTUB: WetLabs Fluorometer. Dive depth in $\mathrm{m}$, dive duration in min, ascent and descent rates in $\mathrm{m} \mathrm{s}^{-1}$ (SD). Unknown sex (U) due to absence of a biopsy sample from the animal

\begin{tabular}{|c|c|c|c|c|c|c|c|c|c|c|}
\hline $\begin{array}{l}\text { Whale } \\
\text { ID }\end{array}$ & $\begin{array}{l}\text { Tag } \\
\text { type }\end{array}$ & $\begin{array}{c}\text { Date } \\
\text { tagged } \\
(\mathrm{mo} / \mathrm{d})\end{array}$ & $\begin{array}{l}\text { Sex } \\
\text { size }\end{array}$ & $\begin{array}{l}\text { Deployment } \\
\text { duration }\end{array}$ & $\begin{array}{l}\text { Mean } \\
\text { dive } \\
\text { depth }\end{array}$ & $\begin{array}{c}\text { Max } \\
\text { dive } \\
\text { depth }\end{array}$ & $\begin{array}{c}\text { Mean } \\
\text { dive } \\
\text { duration }\end{array}$ & $\begin{array}{c}\text { Max } \\
\text { dive } \\
\text { duration }\end{array}$ & $\begin{array}{l}\text { Mean } \\
\text { descent } \\
\text { rate }\end{array}$ & $\begin{array}{l}\text { Mean } \\
\text { ascent } \\
\text { rate }\end{array}$ \\
\hline $2002-01$ & TDR & $5 / 5$ & $\mathrm{~F}, 15 \mathrm{~m}$ & $2 \mathrm{~h} 20 \mathrm{~min}$ & $87(48)$ & 95 & $9(3)$ & 15 & $0.5(0.2)$ & $0.5(0.3)$ \\
\hline $2002-02$ & TDR & $5 / 8$ & $\mathrm{U}, 18 \mathrm{~m}$ & $10 \mathrm{~h} 12 \mathrm{~min}$ & $57(43)$ & 153 & $14(5)$ & 25 & $0.2(0.2)$ & $0.2(0.2)$ \\
\hline $2002-03$ & TDR & $5 / 12$ & $\mathrm{U}, 18 \mathrm{~m}$ & $12 \mathrm{~h} 48 \mathrm{~min}$ & $70(69)$ & 487 & $9(5)$ & 21 & $0.4(0.4)$ & $0.5(0.6)$ \\
\hline 2003-01 & TDR & $5 / 17$ & $\mathrm{~F}, 12 \mathrm{~m}$ & 7 h $50 \mathrm{~min}$ & $54(30)$ & 140 & $5(4)$ & 20 & $0.8(0.5)$ & $1.0(1.1)$ \\
\hline 2003-02 & TDR & $5 / 18$ & $\mathrm{~F}, 15 \mathrm{~m}$ & 8 h 46 min & $90(44)$ & 226 & $9(3)$ & 20 & $0.9(0.3)$ & $0.8(0.5)$ \\
\hline 2005-01 & TDR & $4 / 19$ & $\mathrm{M}, 12 \mathrm{~m}$ & $6 \mathrm{~h} 50 \mathrm{~min}$ & $72(71)$ & 234 & $11(9)$ & 37 & $0.4(0.4)$ & $0.4(0.4)$ \\
\hline 2005-02 & TDR & $4 / 22$ & $\mathrm{M}, 15-18 \mathrm{~m}$ & $54 \mathrm{~h} 41 \mathrm{~min}$ & $73(66)$ & 245 & $18(9)$ & 48 & $0.4(0.4)$ & $0.3(0.4)$ \\
\hline 2005-03 & TDR & $4 / 23$ & $\mathrm{~F}_{1}<12 \mathrm{~m}$ & 21 h $57 \mathrm{~min}$ & $109(41)$ & 192 & $12(5)$ & 27 & $0.8(0.5)$ & $0.8(0.6)$ \\
\hline 2005-04 & FLNTUB & $4 / 22$ & $\mathrm{M}, 15-18 \mathrm{~m}$ & $6 \mathrm{~h} 44 \mathrm{~min}$ & $61(73)$ & 234 & $12(5)$ & 23 & $0.5(0.3)$ & $0.4(0.2)$ \\
\hline 2005-05 & FLNTUB & $4 / 26$ & F, 15-18 m & 8 h 15 min & 94 (124) & 380 & $13(8)$ & 26 & $0.6(0.4)$ & $0.4(0.3)$ \\
\hline 2005-06 & FLNTUB & $4 / 28$ & $\mathrm{U}, 15-18 \mathrm{~m}$ & 5 h $28 \mathrm{~min}$ & $63(38)$ & 158 & 13 (11) & 41 & $0.4(0.1)$ & $0.5(0.1)$ \\
\hline $2005-07$ & FLNTUB & $5 / 3$ & $F, 12-15 \mathrm{~m}$ & $13 \mathrm{~h} 50 \mathrm{~min}$ & $74(34)$ & 183 & $12(5)$ & 25 & $0.5(0.2)$ & $0.4(0.3)$ \\
\hline $2005-08$ & FLNTUB & $5 / 1$ & $F, 12-15 \mathrm{~m}$ & 7 h 57 min & $53(35)$ & 183 & $8(4)$ & 21 & $0.3(0.2)$ & $0.4(0.2)$ \\
\hline 2006-01 & FLNTUB & $5 / 1$ & $\mathrm{U}, 15 \mathrm{~m}$ & $1 \mathrm{~h} 45 \mathrm{~min}$ & $72(30)$ & 110 & $3(2)$ & 7 & $1.8(0.7)$ & $1.7(0.4)$ \\
\hline
\end{tabular}

Table 2. Balaena mysticetus. Estimated kernel area use of satellite tagged bowhead whales in Disko Bay between 2001 and 2006. See Fig. 2 for spatial distribution

\begin{tabular}{|rrrrr|}
\hline \multirow{2}{*}{ Year } & \multirow{2}{*}{ No. whales } & \multicolumn{3}{c|}{ Area use $\left(\mathrm{km}^{2}\right)$} \\
& & $50 \%$ & $75 \%$ & $95 \%$ \\
\hline 2001 & 5 & 829 & 1950 & 3652 \\
2002 & 6 & 751 & 2318 & 4502 \\
2003 & 3 & 335 & 589 & 4089 \\
2005 & 11 & 684 & 1650 & 6897 \\
2006 & 5 & 3494 & 9304 & 35028 \\
& & & & \\
\hline
\end{tabular}

Island, extending offshore about $50 \mathrm{~km}$. The bathymetry within home ranges varied widely and covered areas ranging from a steep coastal slope to trenches of $400 \mathrm{~m}$ depth.

In 2001, the movements of 5 tagged whales were focused along the south coast of Disko Island close to shore and the area use ranged up to $3652 \mathrm{~km}^{2}(95 \%$ kernel) during 4 to 21 May (Table 1, Fig. 2a). In 2002, the area use extended farther west to include Disko Fjord and a larger part of the coast of south Disko Island and covered $4502 \mathrm{~km}^{2}$ (95\% kernel) during 7 to 14 May (Table 1, Fig. 2b). In 2003, area use extended $\sim 90 \mathrm{~km}$ south of Disko Island and the whales used up to $4089 \mathrm{~km}^{2}$ (95\% kernel) during 10 to 21 May (Table 1, Fig. 2c). In 2005, whales used a region similar to that used in 2001; however, it was slightly larger, up to $6897 \mathrm{~km}^{2}$ (95\% kernel), during 16 April to 17 May (Fig. 2d). In 2006, the home range included some area use north of Disko Island; however, whales still concentrated along the south coast of Disko Island, using up to $35028 \mathrm{~km}^{2}$ (95\% kernel) during 6 April to 31 May (Table 1, Fig. 2e).

\section{Diving behavior}

Fourteen archival tags (TDRs and FLNTUBs) were deployed and retrieved on bowhead whales between 2002 and 2006 (Table 2). Tag attachment lasted between $1 \mathrm{~h} 45 \mathrm{~min}$ and $54 \mathrm{~h} 41 \mathrm{~min}$, with an average attachment time of $11 \mathrm{~h} 40 \mathrm{~min}$ for all 14 samples. Most instruments were located and recovered 1 to $2 \mathrm{~d}$ after release from the whale with the ARGOS location data and VHF tracking. Some instruments were retrieved with mud on the instrument package, suggesting recent bottom contact.

Intra- and interanimal variability in diving behavior was high in all years. Mean interwhale dive depths ranged from $53(\mathrm{SD}=35)$ to $109 \mathrm{~m}(\mathrm{SD}=41)$ (Table 2$)$. Dive depths ranged from $12 \mathrm{~m}$ to $487 \mathrm{~m}$ for individual whales, and the maximum depth reached by each individual generally exceeded $150 \mathrm{~m}(80 \%$ of tagged whales made at least 1 dive $>150 \mathrm{~m}$ ). Significant differences in individual mean dive depth were detected $\left(F_{13,607}=4.25, \mathrm{p}<0.001\right)$. Mean dive durations ranged from $3(\mathrm{SD}=2)$ to $18(\mathrm{SD}=9) \mathrm{min}$, yet the maximum dive duration recorded was $48 \mathrm{~min}$. Significant interwhale differences were detected in dive duration $\left(F_{13,607}=18.0, \mathrm{p}<0.001\right)$. Descent rates and ascent rates between individuals ranged widely (Table 2) and were significantly different (Descent $F_{13,599}=22.1, \mathrm{p}<$ 0.0001 , Ascent $F_{13,554}=23.4, \mathrm{p}<0.001$ ). Maximum observed ascent rates were higher than maximum 

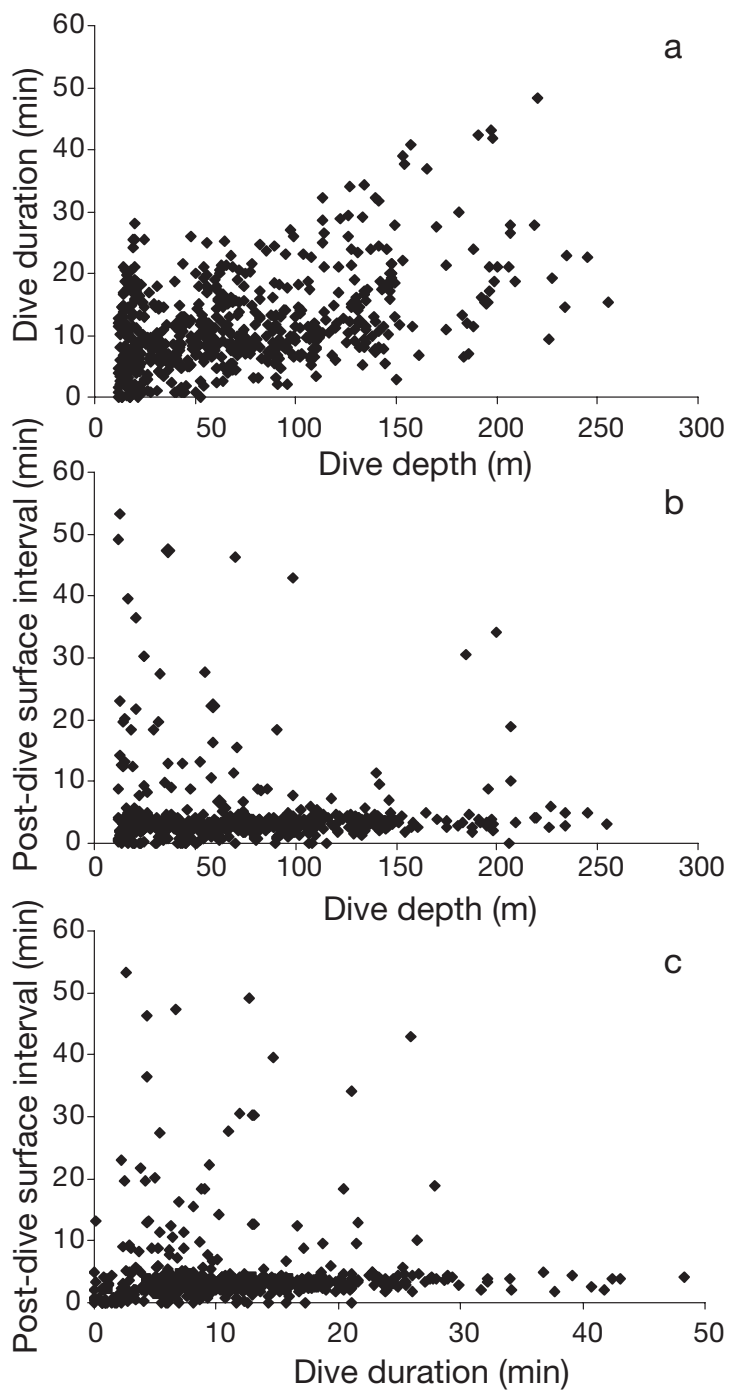

Fig. 3. Balaena mysticetus. Relationship between dive depth and (a) duration, (b) post-dive surface interval and (c) dive duration and post-dive surface interval for 14 bowhead whales tagged with TDRs in Disko Bay between 2002 and 2005 and fluorometers between 2005 and 2006

observed descent rates. Dive duration ranged widely for a given maximum dive depth (Fig. 3a) and the two were poorly correlated. Furthermore, post-dive surface time was not significantly correlated with dive depth or dive duration for any individual (Figs. 3b-c).

Surfacing intervals tended to be short when active diving was observed and over $50 \%$ of post-dive surface intervals, regardless of destination depth, were $<4$ min. Occasionally, diving activity ceased and whales spent extended periods at the surface. These periods of apparent inactivity were characterized by few dives below $12 \mathrm{~m}$ and ranged from $30 \mathrm{~min}$ to $>6 \mathrm{~h}$ in duration.

Dive shapes could be classified into 2 general types. Typical feeding dives were characterized by a rapid

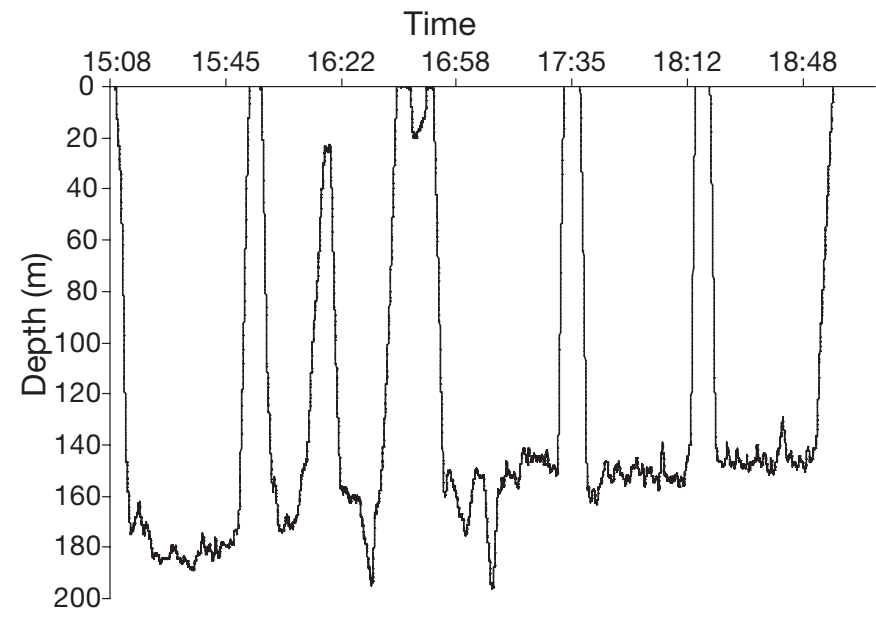

Fig. 4. Balaena mysticetus. Long duration foraging dives of a bowhead whale (ID 2005-02). Each dive lasted between 37 and $43 \mathrm{~min}$ with less than $2 \mathrm{~min}$ of post-dive surface time. Max. potential depth in the area was $200 \mathrm{~m}$

descent to a particular depth, fidelity to that depth $( \pm 5 \mathrm{~m})$ during the bottom time portion of the dive, and then a rapid ascent back to the surface. These foraging dives were generally U-shaped (Fig. 4) with a large proportion of time spent near the bottom and often at the maximum depth in the area. The other type of dive identified resembled a deep V-shaped search dive that traversed a large portion of the water column (generally $>100 \mathrm{~m}$ ) with minimal time spent on the bottom. Often a series of search dives preceded a series of foraging dives with remarkable fidelity to a certain depth.

\section{Zooplankton and water column sampling in 2003}

Stations were evenly distributed in a grid network between 8 and $50 \mathrm{~km}$ off the southwestern corner of Disko Island (Fig. 1). Zooplankton samples were collected from a standardized volume of water $\left(13 \mathrm{~m}^{3}\right)$ between 0 and $50 \mathrm{~m}$, and whenever possible CTD casts were taken to $100 \mathrm{~m}$. CTD data demonstrated a characteristic water column stratification for polar seas, with low saline (33.1 to $33.5 \mathrm{psu}$ ) and high temperature $\left(-0.7\right.$ to $\left.1.0^{\circ} \mathrm{C}\right)$ water masses at the surface extending down to the pycnocline $(20 \mathrm{~m})$. There was no sign of deeper mixing in the water column; however, the deep advection of warm saline water was evident below $70 \mathrm{~m}$. Surface temperature was approximately $1^{\circ} \mathrm{C}$ and declined to about $0.25^{\circ} \mathrm{C}$ at depths of $20 \mathrm{~m}$ before warming again to $1.5^{\circ} \mathrm{C}$ at $100 \mathrm{~m}$.

Zooplankton taxa were pooled into categories representing both the largest proportions of biomass in the study area and the primary prey species for bowhead whales (Table 3). Across the 2003 grid network, cope- 
pods dominated the biomass with Calanus finmarchicus, C. glacialis and C. hyperboreus occurring at 90 to $100 \%$ of all stations, contributing on average $78 \%$ $(\mathrm{SD}=25)$ of the total biomass (interstation range 30 to $97 \%)$. Among the copepods, C. finmarchicus contributed a disproportionate amount of the biomass, outnumbering C. glacialis and C. hyperboreus at least by a factor of 4. Calanus eggs and nauplii were found at all stations. Copepod species from other genera, including Metridia, Oithona, Pseudocalanus, Microcalanus and Acartia, also contributed a large proportion of the total biomass (Table 3). Non-copepod species found frequently included those of Cirripedia, Euphausiacea, Amphipoda and Gastropoda, although these taxa were only identified in nauplii, egg or larval stages and contributed minimally to the total biomass. Mean station biomass measures were normally distributed and ranged between 4 and $233 \mathrm{mg} \mathrm{C} \mathrm{m}^{-3}$. Average interstation biomass for all zooplankton between 0 and $50 \mathrm{~m}$ was $79 \mathrm{mg} \mathrm{C} \mathrm{m}^{-3}(\mathrm{SD}=52)$.

Table 3. Species identified at 25 stations during tows for zooplankton in the upper $50 \mathrm{~m}$ in Disko Bay, West Greenland, May 2003. nd = no data

\begin{tabular}{|c|c|c|c|}
\hline $\begin{array}{l}\text { Plankton } \\
\text { taxa }\end{array}$ & $\begin{array}{l}\text { Included } \\
\text { in biomass } \\
\text { alculations }\end{array}$ & $\begin{array}{l}\text { Occurrence } \\
\text { (\% of Stns) } \\
\text { in } 2003\end{array}$ & $\begin{array}{l}\text { Mean biomass } \\
(\mathrm{SD})\left(\mathrm{mg} \mathrm{C} \mathrm{m}^{-3}\right)\end{array}$ \\
\hline \multicolumn{4}{|l|}{ Copepoda } \\
\hline Calanus finmarchicus & $\mathrm{X}$ & 100 & 49 (39) \\
\hline Calanus glacialis & $\mathrm{X}$ & 90 & $2.8(2.3)$ \\
\hline Calanus hyperboreus & $\mathrm{X}$ & 100 & $12.3(14.9)$ \\
\hline Pseudocalanus spp. & $\mathrm{X}$ & 100 & $0.5(0.3)$ \\
\hline Oithona spp. & $\mathrm{X}$ & 100 & $0.1(0.03)$ \\
\hline Metridia longa & $\mathrm{X}$ & 50 & $0.3(1.1)$ \\
\hline Oncaea spp. & $\mathrm{X}$ & 23 & $<0.01$ (nd) \\
\hline Other Copepoda $^{a}$ & $\mathrm{X}$ & 83 & $<0.01$ (nd) \\
\hline Copepod eggs & $\mathrm{X}$ & 100 & $<0.01$ (nd) \\
\hline Copepod nauplii & $\mathrm{X}$ & 100 & $0.1(0.1)$ \\
\hline \multicolumn{4}{|l|}{ Other invertebrates } \\
\hline Cirripedia & $\mathrm{X}$ & 100 & $0.4(0.5)$ \\
\hline Euphausiacea & $\mathrm{X}$ & 100 & $1.2(1.9)$ \\
\hline Decapoda & $\mathrm{X}$ & 87 & $0.05(0.1)$ \\
\hline Amphipoda (Hyperiidea & ea) $X$ & 100 & $1.5(1.6)$ \\
\hline Gastropoda & $\mathrm{X}$ & 100 & $<0.01$ (nd) \\
\hline Chaetognata & $\mathrm{X}$ & 93 & $10.4(12.6)$ \\
\hline Polychaeta & $\mathrm{X}$ & 93 & $0.04(0.1)$ \\
\hline Appendicularia & & 33 & \\
\hline Hydrozoa & & 93 & \\
\hline Echinodermata & & 10 & \\
\hline Ostracoda & & 50 & \\
\hline Ctenophora & & 3 & \\
\hline Protozoa & & 3 & \\
\hline Isopoda & & 13 & \\
\hline Arachnidae & & 3 & \\
\hline Nemertini & & 3 & \\
\hline Bivalvia & & 3 & \\
\hline Fish larvae and eggs & & 33 & $0.02(0.04)$ \\
\hline
\end{tabular}

Interpolated spatial gradients in biomass in 2003 were higher in the eastern and offshore part of the bay, with lower biomass occurring in the western part and at shallow depths (Fig. 5). The low biomass in the western portion of the bay (ranging from 4 to $50 \mathrm{mg} \mathrm{C} \mathrm{m}^{-3}$ ) spatially coincided with the $50 \%$ probability home range in 2003 (Fig. 2c). Biomass levels $>200 \mathrm{mg} \mathrm{C} \mathrm{m}^{-3}$ were found in areas where few satellite positions were received from whales in 2003.

\section{Zooplankton and water column sampling in 2005}

The standard station in 2005 demonstrated the temporal trend in the development of primary production in Disko Bay. Low chl a values were recorded in the upper $50 \mathrm{~m}$ of the water column until late March, after which phytoplankton biomass increased exponentially

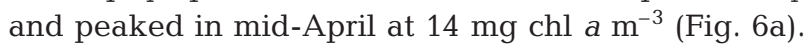
Copepod biomass peaked between the end of April and early May at $2500 \mathrm{mg} \mathrm{C} \mathrm{m}^{-2}$ (Fig. 6b). The temporal trend of the ascension of copepods to the upper $50 \mathrm{~m}$ was essentially linear and densities reached an asymptote at levels of $\sim 2000 \mathrm{mg} \mathrm{C}$ $\mathrm{m}^{-2}$ by June.

The additional focal area sampled in 2005 corresponded to the region used heavily by feeding whales. Biomass values in 2003 and 2005 were compared for 9 stations (Figs. 5 \& 7). Biomass to $50 \mathrm{~m}$ was lower in 2005 than in 2003 (between 1 and $16 \mathrm{mg} \mathrm{C} \mathrm{m}^{-3}$ ); however, increasing trends with increasing distance from the coast were found in both years. Copepod biomass was 5 to 15 times higher at depths $>150 \mathrm{~m}$ where whales concentrated diving activity (Fig. 8). This was the same region where biomass above $50 \mathrm{~m}$ was negatively correlated with whale occurrence in 2003 (Fig. 5).

\section{Zooplankton and water column sampling in 2006}

In 2006, 3 sites (Sorte Sand, Fortune Bay and Laksebugten) were sampled for zooplankton concentrations from the surface to the bottom in $15 \mathrm{~m}$ increments and in 5 replicates (Fig. 1). At all sites the biomass of copepods and Pandalus sp. increased by several orders of magnitude from the surface of the water column $(<1 \mathrm{mg} \mathrm{C}$ $\mathrm{m}^{-3}$ ) to an average biomass of $353 \mathrm{mg} \mathrm{C} \mathrm{m}^{-3}$ at $40 \mathrm{~m}$ on the bottom (Fig. 9). Pandalus sp. was the dominant species found in samples obtained between 30 and $75 \mathrm{~m}$, but between 75 and $115 \mathrm{~m}$ C. finmarchicus was found in quantities several 


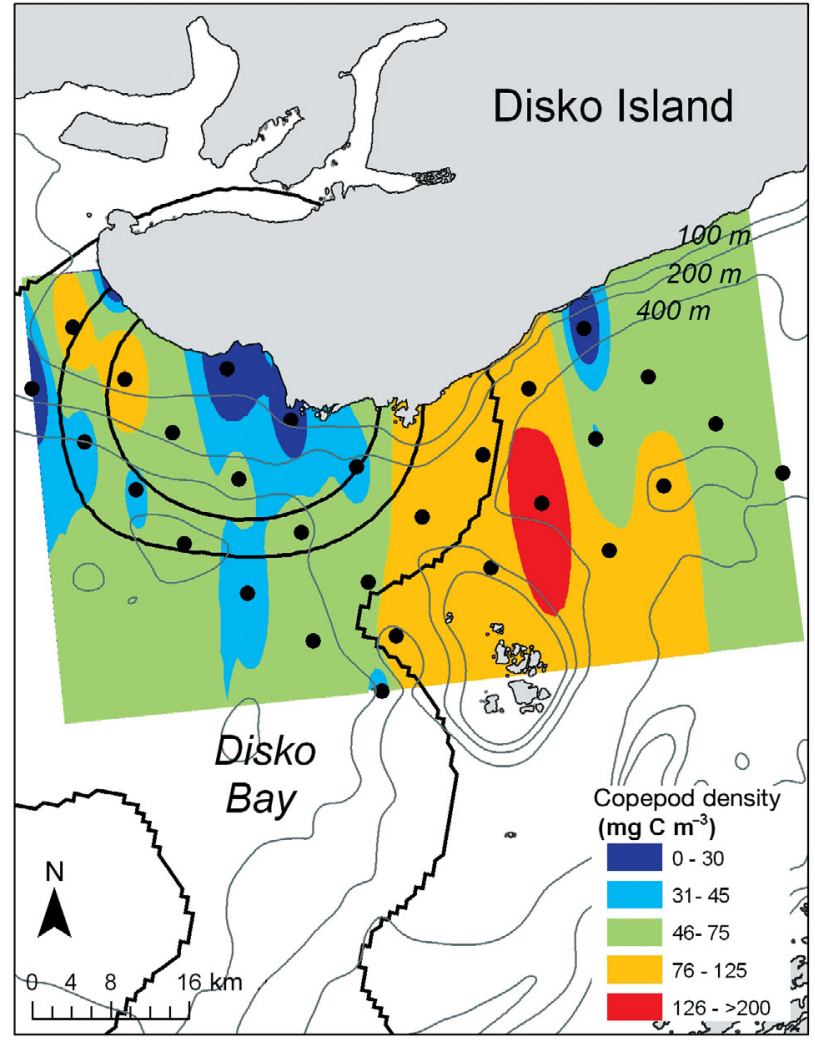

Fig. 5. Balaena mysticetus. Interpolated mean copepod biomass $\left(\mathrm{km}^{-2}\right)$ in Disko Bay in May 2003. Biomass density is shown with bowhead kernel home range contours (black; depth contours gray) from May 2003 (based on satellite tagged whales, Fig. 2c). Note the negative correlation between whale focal area use and biomass between 0 and $50 \mathrm{~m}$. ( $)$ : station locations

orders of magnitude higher than in all other prey categories or depths (Fig. 9).

\section{Bioenergetic model}

The bioenergetic model produced a daily energy requirement of $2.67 \times 10^{8} \mathrm{kcal} \mathrm{d}^{-1}\left(\mathrm{SE}=9.7 \times 10^{5}\right)$ for the $250(\mathrm{CV}=0.35)$ bowhead whales in Disko Bay. The adult female portion of the population had the highest energy requirements, $1.2 \times 10^{8} \mathrm{kcal} \mathrm{d}^{-1}\left(\mathrm{SE}=4.4 \times 10^{5}\right)$ with adult male stage class following them at $9.8 \times 10^{7}$ $\mathrm{kcal} \mathrm{d}^{-1}\left(\mathrm{SE}=3.6 \times 10^{7} \mathrm{kcal} \mathrm{d}^{-1}\right)$. Daily energetic needs of the population were met with approximately $223 \mathrm{t}$ ( $\mathrm{SE}=0.8$ ) of zooplankton. Thus, the estimated biomass of zooplankton required by the total population of bowheads over the 4 mo period was $26798 \mathrm{t}(\mathrm{SE}=97$ ), assuming energetic requirements for an individual are met every day in Disko Bay.

The mean biomass of zooplankton in the upper $50 \mathrm{~m}$ in May 2003 was estimated as $79 \mathrm{mg} \mathrm{C} \mathrm{m}^{-3}$. Using a
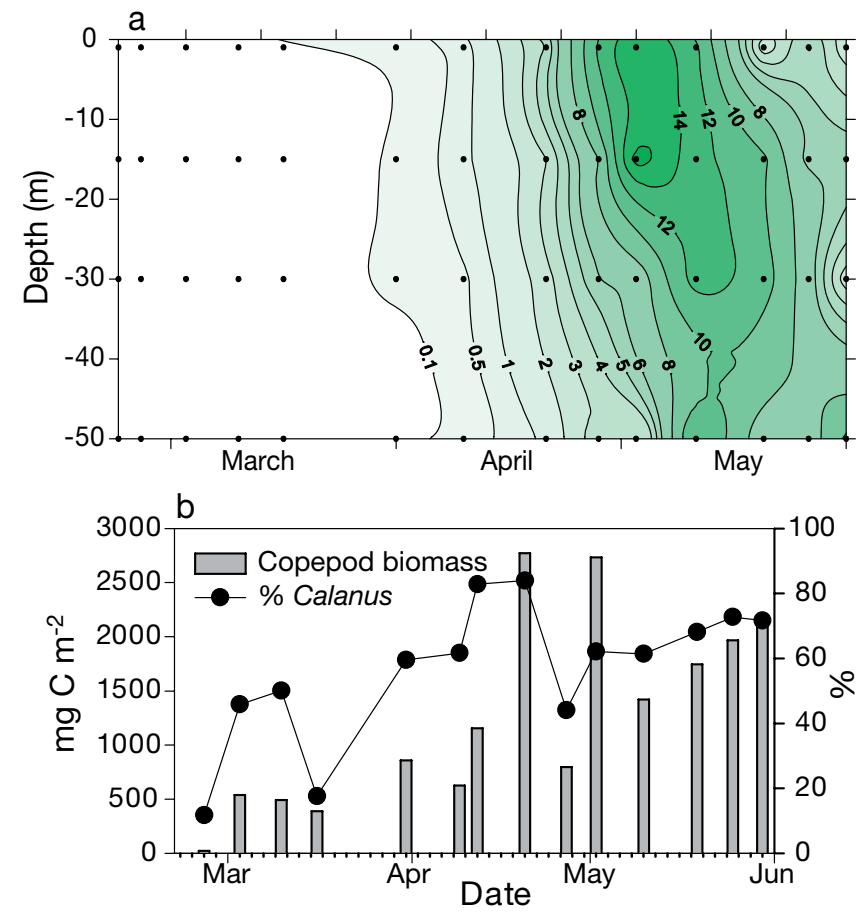

Fig. 6. (a) Depth distribution of phytoplankton ( $\mathrm{mg} \mathrm{chl} \mathrm{a} \mathrm{m}^{-3}$ ). Points represent samples in time and the water column.

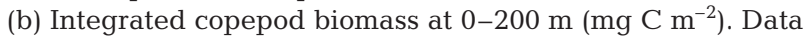
collected from the single standard station monitored weekly between March and June 2005

carbon content of $40 \%$ of dry weight (Karnovsky et al. 2003), the biomass estimate of zooplankton corresponds to $2.6 \times 10^{7} \mathrm{mg}$ dry weight. An energy density of $26 \mathrm{~kJ} g$ dry weight (Karnovsky et al. 2003) results in $0.001 \mathrm{~kg} \mathrm{~m}^{-3}$ of copepods in the upper $50 \mathrm{~m}$ of the water column, or approximately 122770 t of zooplankton in the $2600 \mathrm{~km}^{2}$ sampled area. Thus, if bowheads were to feed only in the upper $50 \mathrm{~m}$ of the water column, they would (at the current population size) remove approximately $22 \%$ of the pelagic biomass in spring.

\section{DISCUSSION}

\section{Bowhead foraging behavior}

The U-shaped feeding dives observed in this study are characteristic for baleen whales exploiting patches of zooplankton (Baumgartner \& Mate 2003, Baumgartner et al. 2003). The remarkable fidelity to a specific depth suggests that once high or sufficient densities of zooplankton are located, the dive duration at that depth is maximized and the same depth is targeted repeatedly. In this study, target depths were highly variable given that bowhead whale foraging 


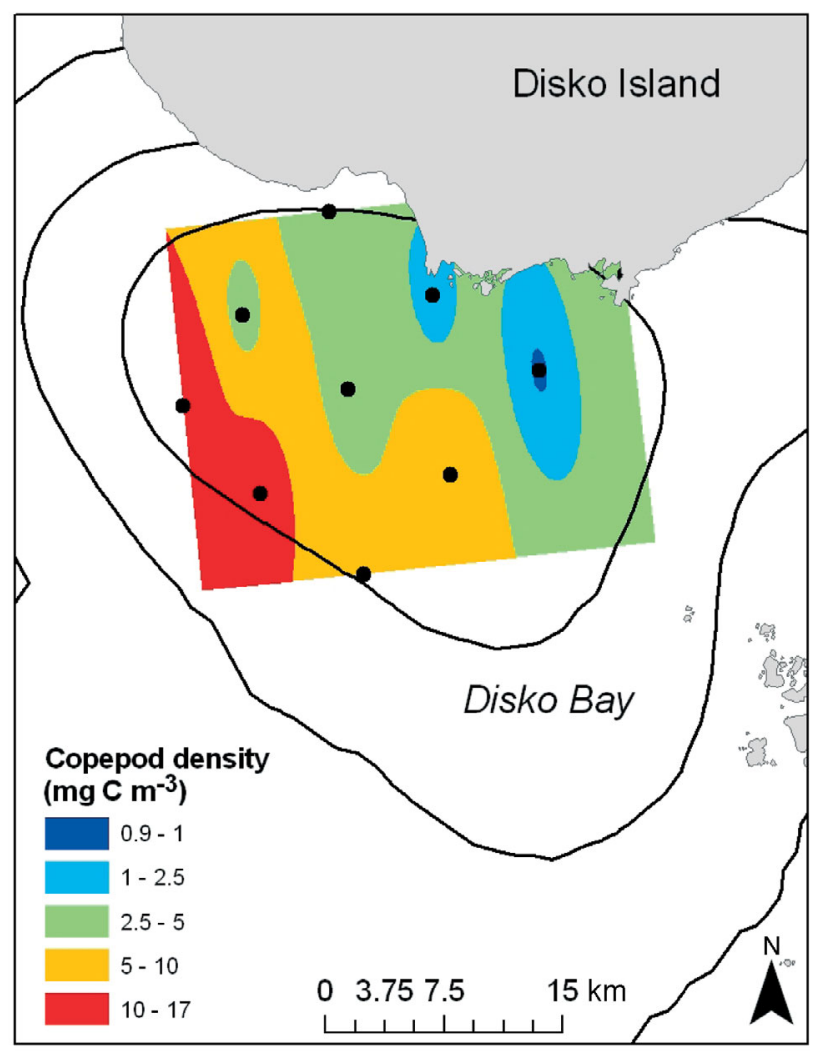

Fig. 7. Spatial interpolation of copepod biomass in 2005 for 9 grid stations and 1 standard station in May between 0 and $50 \mathrm{~m}$ superimposed with 2005 kernel home range contours $(50,75$ and $95 \%)$ from satellite tagged bowhead whales (see Fig. 2d)

occurred on the seabed in an area with a large gradient in bottom depths. Whales actively foraged at 80 to $200 \mathrm{~m}$, corresponding well to the bottom contours along the slope. The functional relationship between U-shaped feeding and V-shaped searching dives probably facilitates an active search for discrete layers of zooplankton before initiation of foraging dives.

In this study, bowheads dove to a maximum of $487 \mathrm{~m}$, and in many cases whales targeted depths of $>200 \mathrm{~m}$ repeatedly. In the Beaufort Sea, bowhead whales have been reported to make shallower dives (50 to $100 \mathrm{~m}$ ) for calanoid copepods on the bottom (Krutzikowsky \& Mate 2000). The dive of $487 \mathrm{~m}$ recorded during this study is the deepest dive measured for a bowhead whale.

Dive durations measured for foraging bowhead whales were surprisingly longer than those reported for other baleen whales. Dives lasted up to $48 \mathrm{~min}$ and in several cases whales repeatedly dove for 30 to $40 \mathrm{~min}$ at a time with post-dive times spent at the surface lasting $<2 \mathrm{~min}$. Mean dive durations in this study (5 to $18 \mathrm{~min}$ ) are similar to those for the right whale Eubalaena glacialis (12 min); however, maximum values are much higher than those for right whales
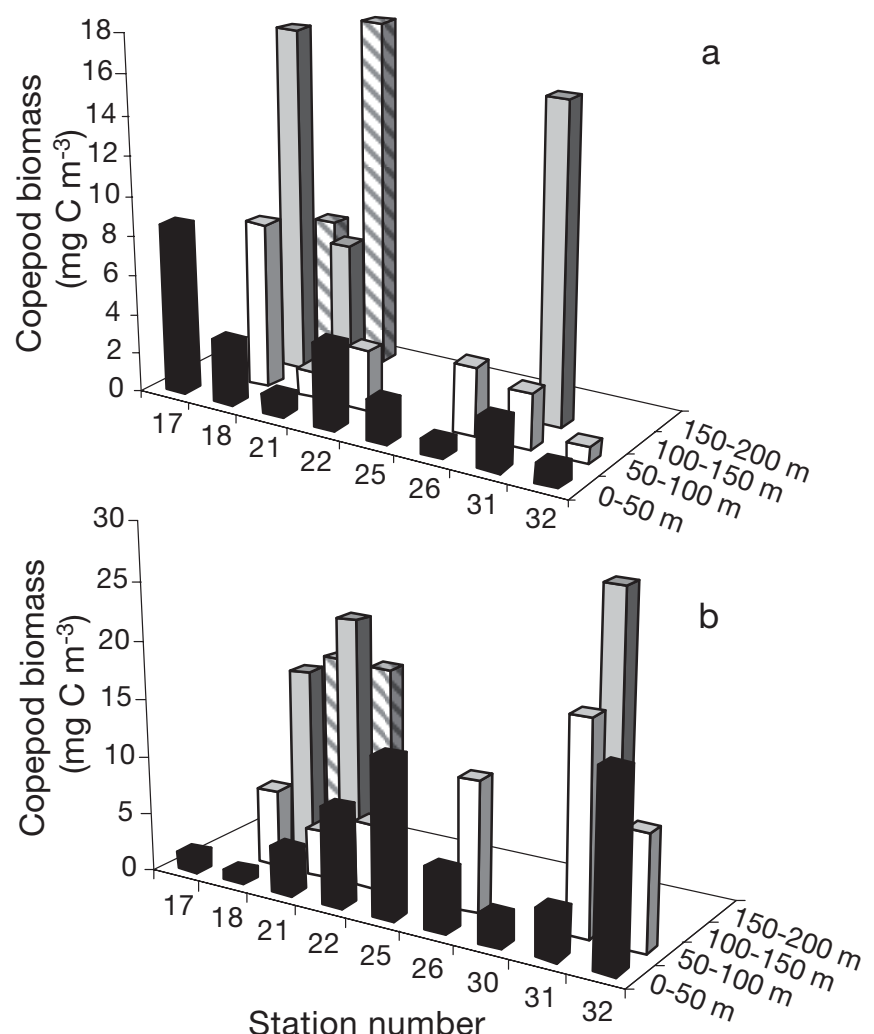

Fig. 8. Biomass of copepods from $0-200 \mathrm{~m}$ in (a) April and (b) May 2005. Zooplankton were sampled in $50 \mathrm{~m}$ increments of the water column at 9 standard stations. Not all stations had depths up to $200 \mathrm{~m}$ : some data are missing

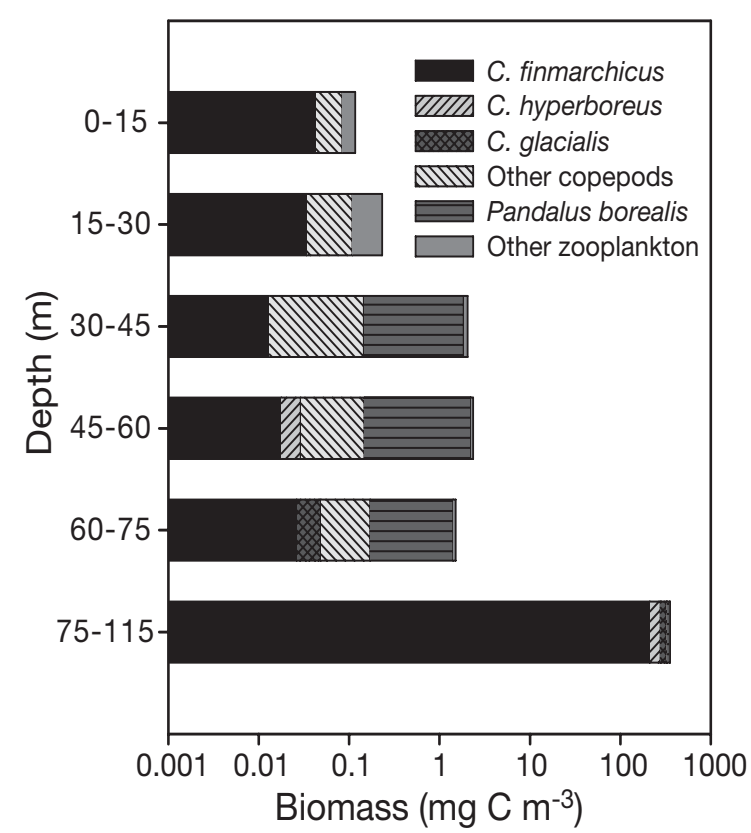

Fig. 9. Depth distribution of log zooplankton biomass in Fortune Bay, April 2006. Bottom samples taken $<1 \mathrm{~km}$ from the coast in Disko Bay. C.: Calanus 
(16 min) (Baumgartner \& Mate 2003). The fin whale Balaenoptera physalus and the blue whale B. musculus have shorter foraging dive durations (mean, 6 to $7 \mathrm{~min}$ ) and it has been suggested that continuous filter feeding in bowhead and right whales lowers metabolic rates and enables these species to maintain higher dive durations (Croll et al. 2001).

Krutzikowsky \& Mate (2000) reported bowhead whale dive durations exceeding $60 \mathrm{~min}$ in the Beaufort Sea. Furthermore, bowhead whales have been reported to stay submerged for $>80$ minutes when harpooned (Scoresby 1820, Scammon 1874), and this species may have a diving capacity far beyond that of other baleen whales (Figs. 3a \& 4).

Bowhead whales appear to have large flexibility in their use of the water column. There was no correlation between dive depth and duration and no correlation with post-dive surface interval (i.e. recovery time). This is in contrast to strong positive correlations between dive duration and dive depth for right whales that focus on dense patches of zooplankton (Baumgartner \& Mate 2003).

Bowhead whales in Alaska feed between spring and fall in the water column and on the bottom or nearbottom on larger amphipods and euphausiids (Lowry 1993, Lowry et al. 2004). Lowry (1993) and Lowry et al. (2004) found hundreds of prey species in the stomachs of harvested bowhead whales between Point Barrow and Kaktovik and differences in the seasonal proportion of species in stomachs was consistent with seasonal patterns of zooplankton abundance.

\section{Bowhead prey items}

Bowhead whales have been postulated to filter feed on zooplankton at depths just below the euphotic zone after the ascension of the secondary production. Therefore, the lack of relationship between high densities of prey in the upper $50 \mathrm{~m}$ of the water column and bowhead dive behavior and area use was surprising. The major portion of the spring zooplankton biomass in the upper $50 \mathrm{~m}$ of Disko Bay consists of Calanoid copepods, primarily Calanus finmarchicus, a North Atlantic species that successfully reproduces and recruits in polar ecosystems (Pedersen et al. 2005, Thor et al. 2005). Studies of interannual variation in the upper $50 \mathrm{~m}$ of the water column in Disko Bay indicate that zooplankton biomass can vary by $>30 \%$ (Thor et al. 2005). The predictability of prey for bowhead whales in surface waters is therefore low. Bowhead whales occupy a seasonally dynamic environment with brief optimal foraging conditions. Thus, maintaining a foraging strategy that targets the densest and most predictable prey concentrations (i.e. near seabed zoo- plankton) offers insurance against interannual fluctuations in prey abundance at the surface. Bowheads ingest about 10 times as much phytoplankton as copepods while foraging (750 $\mathrm{mg} \mathrm{C} \mathrm{m} \mathrm{C}^{-3}$ of phytoplankton vs. $79 \mathrm{mg} \mathrm{C} \mathrm{m}^{-3}$ of Calanus); however, the extent of the importance of diatoms in the diet of bowhead whale is unknown.

\section{Bowhead energetics}

Uncertainties in metabolic rates, feeding time for baleen whales and energetic densities of zooplankton (Costa et al. 2006) inhibit the ability to accurately model caloric needs. Several unknown and estimated parameters make bioenergetic considerations for large baleen whales simply an approximation.

Bowheads migrate seasonally between local Arctic hot spots with high densities of zooplankton. Studies of the movements of bowhead whales from satellite telemetry show intense and localized use of a single site for 3 to $6 \mathrm{wk}$ interspersed with long distance movements $(>1000 \mathrm{~km})$ occurring over 1 to $2 \mathrm{wk}$ (HeideJørgensen et al. 2006). Travel speeds are too high (up to $200 \mathrm{~km} \mathrm{~d}^{-1}$ ) for foraging to be feasible during these long distance movements, and whales traverse offshore deep areas, regions that contain little to no zooplankton. Thus, it is possible that bowhead whale caloric needs are not met on a daily basis; instead, they are obtained during intense foraging periods with little to no feeding between sites. Their large body size likely acts as a buffer from the variability in pelagic productivity and allows the species to move long distances over long periods of time between regions of patchy and ephemeral productivity.

Technically, the densities of zooplankton above the $50 \mathrm{~m}$ depth in Disko Bay are sufficient to support the energetic demands of the population. However, the question remains as to the amount of water that needs to be filtered to meet these caloric needs and if zooplankton densities are even sufficiently high enough to warrant filter feeding by bowheads. Given the bioenergetic estimates, bowheads would need to filter more than $200 \times 10^{6} \mathrm{~m}^{3}$ of water daily, or $22 \%$ of the total volume of water that exists between 0 and $50 \mathrm{~m}$ in their home range, during a 4 mo period. Densities of copepods rapidly increase with depth, especially below $150 \mathrm{~m}$, and copepod densities are orders of magnitude higher near or on the bottom. The dive data indicate that bowhead whales make deep dives, following the highly complex bottom contours of Disko Bay in areas where epibenthic densities of copepods are dramatically greater (Figs. 8a, b \& 9). Given the requirement to strain enormous quantities of water, large whales have likely evolved to exploit their zooplankton prey in 
regions with high density aggregations (see Baumgartner \& Mate 2003, Croll et al. 2005,). Little is known about the fine scale spatial variability of these patches or how much time bowhead whales must spend searching for them.

Affinity of whales to the southern coast of Disko Island has been known for hundreds of years (Eschricht \& Reinhardt 1866). It is likely that this particular area affords unparalleled feeding opportunities due to physical patterns in water temperatures, upwelling, currents or high densities of lipid rich Arctic zooplankton species (Lee et al. 2006). Eschricht \& Reinhardt (1866) reported on departure dates of bowhead whales in Disko Bay between 1780 and 1837 with a mean date for the last sighting of whales of 1 June (range, 26 April to 25 June). Bowhead whales in this study departed between 10 and 21 May, precisely following observations from the past 2 centuries. Bowhead whales depart from Disko Bay before the ascension and peak densities of copepods in the water column (Fig. 6b); this has also been noted for whales in the Bering Sea (Lowry 1993).

Bowhead whales in West Greenland focus foraging effort on benthic zooplankton in coastal zones, the spatial distribution of which probably results from a combination of coastal upwelling and complex bottom topography funneling or channeling prey. The steep shelf off the coast of Disko Island (0 to $400 \mathrm{~m}$ across $4 \mathrm{~km}$ ) makes a large range of complex and deep depths available to whales over a small horizontal area, and Disko Bay is known as one of the most productive areas in West Greenland (Heide-Jørgensen and Laidre 2004).

In this study, the combination of observations of bowhead whale foraging behavior collected by satellite and archival telemetry combined with intensive and localized in situ sampling of ocean conditions provided a tool for merging the dynamic and complex relationships between prey availability and feeding patterns. Few other methodological approaches can be used to obtain such information about the foraging ecology of a large pelagic predator, given the 3-dimensional spatial and temporal scales over which the mechanisms of physical forcing, production patterns and prey aggregation occur. The seasonally dependable dense aggregations of zooplankton in specific localities around the Arctic likely play an important role in the recovery of the eastern Arctic bowhead whale population.

Recent studies from a variety of ecosystems demonstrate that climate change can decouple species from favorable food conditions (Post et al. 2001, Thomas et al. 2001, Winder \& Schindler 2004). Given the considerable abrupt reductions in seasonal Arctic sea ice extent (Holland et al. 2006), the projected rates of ice loss through the 21st century (Serreze et al. 2007), and the close coupling between sea ice and the dynamics of phytoplankton and zooplankton (Heide-Jørgensen et al. 2007), it is likely the springtime foraging conditions encountered by bowhead whales in Disko Bay will be altered. Biotic factors like competition and predation become more important at higher levels of the food chain; thus, long-term studies of the ecosystem, including physical and multiple trophic levels, are required to develop a holistic understanding of how climate change will affect bowhead whales.

Acknowledgements. Bowhead whale tagging and zooplankton data collection were funded by the Commission for Scientific Research in Greenland, the Carlsberg Foundation, the Danish Cooperation for the Environment in the Arctic (DANCEA), the Department of Fisheries and Oceans Canada and the Greenland Institute of Natural Resources. Mikkel Villum Jensen assisted with the development of TDRs, and together with Hans Christian Schmidt and Anders Villum Jensen participated in the tagging. Søren Anker Pedersen provided guidance with euphausiid biomass calculations. Outi Tervo, Jens Larsen and Signe Juul Madsen assisted with oceanographic and zooplankton sampling. Thanks are extended to the University of Copenhagen for providing access to Arktisk Station and to the crew of RV 'Porsild' for field assistance. Canada Department of Fisheries and Oceans provided genetic determination of the sexes of whales. K.L.L. was funded by NSF grant \# 0401077 and T.G.N. supported by Danish National Research Council grant \# 9801391. Research was conducted under permits obtained from the Greenland Home Rule government.

\section{LITERATURE CITED}

Baumgartner MF, Mate BR (2003) Summertime foraging ecology of North Atlantic right whales. Mar Ecol Prog Ser 264: 123-135

Baumgartner MF, Cole TVN, Campbell RG, Teegarden GJ, Durbin EG (2003) Associations between North Atlantic right whales and their prey, Calanus finmarchicus, over diel and tidal time scales. Mar Ecol Prog Ser 264:155-166

Berggreen U, Hansen B, Kiørboe T (1988) Food size spectra, ingestion and growth of the copepod Acartia tonsa during development: implications for determination of copepod production. Mar Biol 99:341-352

Brody PF (1945) Bioenergetic growth, with special reference to the efficiency complex in domestic animals. Hafner Publishing Company, New York

Costa AD, Durbin EG, Mayo CA (2006) Variability in the nutritional value of the major copepods in Cape Cod Bay (Massachusetts, USA) with implications for right whales. PSZN I: Mar Ecol 27:109-116

Croll DA, Acevedo-Gutiérrez A, Tershy BR, Urbán-Ramírez J (2001) The diving behavior of blue and fin whales: is dive duration shorter than expected based on oxygen stores? Comp Biochem Physiol A Comp Physiol 129:797-809

Croll DA, Marinovic B, Benson S, Chavez FP, Black N, Ternullo R, Tershy BR (2005) From wind to whales: trophic links in a coastal upwelling system. Mar Ecol Prog Ser 289:117-130

Cushing, DH (1974) Sea fisheries research. John Wiley and Sons, New York

Eschricht DF, Reinhardt J (1866) Om Nordhvalen (Balaena mysticetus L.) navnlig med Hensyn til dens Udbredning i Fortiden og Nutiden og til dens ydre og indre Saerkjender. K. Danske Videnskabernes Selskabs Skrifter, Series 5. 
Naturvidensk Mathemat Afdel 5:433-590

Hansen B (1999) Cohort growth of planktotrophic polychaete larvae-are they food limited? Mar Ecol Prog Ser 178: 109-119

Hansen B, Ockelmann KW (1991) Feeding behavior in the opisthobranch Philine aperta: I. Growth and functional response at different developmental stages. Mar Biol 111: $255-261$

Heide-Jørgensen MP, Acquarone M (2002) Size and trends of the bowhead, beluga and narwhal stocks wintering off West Greenland. Sci Publ N Atl Ma Mamm Comm 4: 191-210

Heide-Jørgensen MP, Laidre KL (2004) Declining open water refugia for top predators in Baffin Bay and adjacent waters. Ambio 33:488-495

Heide-Jørgensen MP, Laidre KL, Wiig O, Jensen MV, Dueck L, Maiers L, Schmidt HC, Hobbs RC (2003) From Greenland to Canada in two weeks: movements of bowhead whales, Balaeana mysticetus, in Baffin Bay. Arctic 56:21-31

Heide-Jørgensen MP, Laidre KL, Jensen MV, Dueck L, Postma LD (2006) Dissolving stock discreteness with satellite tracking: bowhead whales in Baffin Bay. Mar Mamm Sci 22:34-45

Heide-Jørgensen MP, Laidre KL, Logsdon ML, Nielsen TG (2007) Springtime coupling between phytoplankton, sea ice and sea temperature in Disko Bay, West Greenland. Prog Oceanogr 73:79-95

Hirche HJ, Mumm N (1992) Distribution of dominant copepods in the Nansen Basin, Arctic Ocean, in summer. Deep Sea Res 39 (Suppl 2):485-505

Holland MM, Bitz CM, Tremblay B (2006) Future abrupt reductions in the summer Arctic sea ice. Geophys Res Lett 33, L23503 doi:10.1029/2006GL028024

Hoodge PN, Eichenlaub B (1997) Animal movement extension to Arcview. ver. 1.1. US Geological Survey, Alaska Biological Science Center, Anchorage, AK

Hygum BH, Rey C, Hansen BW (2000) Growth and development rates of Calanus finmarchicus nauplii during a diatom spring bloom. Mar Biol 136:1075-1085

Innes S, Lavigne DM, Earle WM, Kovacs KM (1987) Feeding rates of seals and whales. J Anim Ecol 56:115-130

Karnovsky NJ, Kwaśniewski S, Węslaswski JM, Walkusz W, Beszczyńska-Möller A (2003) Foraging behavior of little auks in a heterogeneous environment. Mar Ecol Prog Ser 253:289-303

Kiørboe T, Møhlenberg F, Hamburger K (1985) Bioenergetics of the planktonic copepod Acartia tonsa: relation between feeding, egg production and respiration, and composition of specific dynamic action. Mar Ecol Prog Ser 26:85-97

Klein Bretler WCM, Fransz HG, Gonzalez SR (1982) Growth and development of four calaniod copepod species under experimental and natural conditions. Neth J Sea Res 16: 195-207

Kleiber M (1975) The fire of life: an introduction to animal energetics. Robert E. Krieger Publishing, Huntington, New York

Kenney RD, Scott GS, Thompson TJ, Winn HE (1997) Estimates of prey consumption and trophic impacts of cetaceans in the USA Northeast Continental Shelf ecosystem. J Northwest Atl Fish Sci 22:155-171

Krutzikowsky GK, Mate BR (2000) Dive and surfacing characteristics of bowhead whales (Balaena mysticetus) in the Beaufort and Chukchi seas. Can J Zool 78:1182-1198

Laidre KL, Stirling I, Lowry L, Wiig Ø, Heide-Jørgensen MP, Ferguson S (2007) Quantifying the sensitivity of arctic marine mammals to climate-induced habitat change. Ecol Appl (in press)

Lee, RF, Hagen W, Kattner G (2006) Lipid storage in marine zooplankton. Mar Ecol Prog Ser 307:273-306

Lowry LF (1993) Foods and feeding ecology. In: Burns JJ, Montague JJ, Cowles CJ (eds) The bowhead whale. Soc Mar Mamm Spec Publ No. 2. Allen Press, Lawrence, KS, p 201-283

Lowry LF, Sheffield G, George JC (2004) Bowhead whale feeding in the Alaskan Beaufort Sea, based on stomach contents analyses. J Cetacean Res Manag 6:215-223

Lockyer C (1981) Growth and energy budgets of large baleen whales from the southern hemisphere. In: Mammals in the sea, Vol 3. General Papers and Large Cetaceans, FAO Fish Ser 5:379-487

Pedersen SA, Ribergaard MH, Simonsen CS (2005) Microand mesozooplankton in Southwest Greenland waters in relation to environmental factors. J Mar Sys 56:85-112

Pedersen TJ, Nielsen TG, Michel C, Møller EF and 5 others (2006) Sedimentation following the spring bloom in Disko Bay, West Greenland, with special emphasis on the role of copepods. Mar Ecol Prog Ser 314:239-255

Post E, Forchammer MC, Stenseth NC, Callaghan TV (2001) The timing of life-history events in a changing climate. Proc R Soc Biol Ser B 268:15-23

Reeves RR, Leatherwood S (1985) Bowhead whale, Balaena mysticetus Linnaeus 1758. In: Ridgeway SH, Harrison R (eds) Handbook of marine mammals, Vol 3: the sirenians and baleen whales. Academic Press, London, p 305-344

Sabatini M, Kiørboe T (1994) Egg production, growth and development of the cyclopoid copepod Oithona similis. J Plankon Res 16:1329-1351

Scammon CM (1874) The marine mammals of the northwestern coast of North America together with an account of the American whale fishery. J.H. Carmany, San Francisco (reprinted 1968, Dover Publications, New York)

Scoresby Jr W (1820) An account of the Arctic regions with a history and description of the northern whale-fishery. Archibald Constable, Edinburgh (reprinted 1969 Newton Abbot, Devon)

Serreze MC, Holland MM, Stroeve J (2007) Perspectives on the Arctic's shrinking sea ice cover. Science 315:1533-1536

Thomas DW, Blondel J, Perret P, Speakman JR (2001) Energetic and fitness costs of mismatching resource supply and demand in seasonally breeding birds. Science 291: $2598-2600$

Thor $\mathrm{P}$, Nielsen TG, Tiselius $\mathrm{P}$, Juul-Pedersen $\mathrm{T}$ and 5 others (2005) Post spring bloom community structure of copepods in the Disko Bay, Western Greenland. J Plankton Res 27: 341-356

Turner JT, Levinsen H, Nielsen TG, Hansen BW (2001) Zooplankton feeding ecology: grazing on phytoplankton and predation on protozoans by copepod and barnacle nauplii in Disko Bay, West Greenland. Mar Ecol Prog Ser 221:209-219

Tynan CT, Ainely DG, Barth JA, Cowles TJ, Pierce SD, Spear LB (2005) Cetacean distribution relative to ocean processes in the northern California Current system. Deep Sea Res II 52:145-167

Uye S (1982) Length-weight relationships of important zooplankton from the inland Sea of Japan. J Oceanogr Soc Jpn 38:149-158

Winder M, Schindler DW (2004) Climate change uncouples trophic interactions in a lake ecosystem. Ecology 85:56-62

Winship AJ, Trites AW, Rosen DAS (2002) A bioenergetic model for estimating the food requirements of Steller sea lions (Eumetopias jubatus) in Alaska, USA. Mar Ecol Prog Ser 229:291-312

Yasui WY, Gaskin DE (1986) Energy budget of a small cetacean, the harbour porpoise, Phocoena phocoena (L.). Ophelia 25:183-197 